\title{
SOSIALISASI SEDIAAN KRIM EKSTRAK DAUN NANGKA (ARTOCARPUS HETEROPHYLLUS L.) TERHADAP BAKTERI PROPIONIBACTERIUM ACNE
}

\author{
Fahma Shufyani ${ }^{1 *}$,Dewi Kartika ${ }^{1}$, Jhon Patar Sinurat ${ }^{2}$ \\ ${ }^{1}$ Program Studi Farmasi, Institut Kesehatan Medistra Lubuk Pakam \\ ${ }^{2}$ Program Studi Teknologi Laboratorium Medik, Institut Kesehatan Medistra Lubuk Pakam \\ JIn. Sudirman No.38 Lubuk Pakam, Kabupaten Deli Serdang, \\ Sumatera Utara - Indonesia \\ *email korespondensi author: fahmaapotekerunand@yahoo.co.id
}

DOI $10.35451 /$ jpk.v1i1.706

\begin{abstract}
Abstrak
Daun nangka (Artocarpus heterophyllus L) merupakan salah satu bahan alami yang dapat digunakan sebagai terapi pengobatan jerawat. Untuk memudahkan penggunaan ekstrak dibuat dalam bentuk krim. Senyawa yang berperan sebagai antibakteri pada daun nangka antara lain flavonoid, tanin, saponin. Metode ekstraksi yang digunakan adalah metode maserasi. Uji yang dilakukan pada sediaan krim meliputi tes stabilitas fisik dan tes aktivitas anti-jerawat. Uji stabilitas sediaan fisik dilakukan setiap 6 hari sekali selama 3 minggu. Sedangkan uji observasi aktivitas anti acne dilakukan terhadap bakteri Propionibacterium acne. Berdasarkan pengamatan organoleptik didapatkan formulasi 1 dan 2 tidak ada perubahan sedangkan 3,4,5 ada perubahan. Uji aktivitas anti acne menunjukkan bahwa formulasi pengujian pertama lebih efektif dari pada pengujian ke dua dengan zona hambat rata-rata 9,5 $\mathrm{mm}$.
\end{abstract}

Kata Kunci: Krim, daun nangka, Propionibacterium acne

\begin{abstract}
Jackfruit leaf (Artocarpus heterophyllus $L$ ) is one of the natural ingredients that can be used as acne treatment therapy. For ease of use the extract is made in the form of a cream. Compounds that act as antibacterial in jackfruit leaves include flavonoids, tannins, and saponins. The extraction method used is the maceration method. Tests carried out on cream preparations include physical stability tests and anti-acne activity tests. The stability test of the physical preparation was carried out every 6 days for 3 weeks. While the anti-acne activity observation test was carried out on Propionibacterium acne bacteria. Based on organoleptic observations, formulations 1 and 2 showed no change, while 3,4,5 showed no change. The anti acne activity test showed that the formulation of the first test was more effective than the second test with an average inhibition zone of $9.5 \mathrm{~mm}$.
\end{abstract}

Keywords: Cream, Jackfruit leaf, Propionibacterium acne

\section{Pendahuluan}

Acne vulgaris atau jerawat adalah suatu kondisi inflamasi umum pada bagian organ kulit yang disebut unit polisebaseus yang terjadi pada remaja dan dewasa muda yang ditandai dengan komedo, papul, pustul, nodul.
Meskipun acne tidak berdampak fatal, tetapi dapat cukup merisaukan karena berhubungan dengan menurunnya kepercayaan diri akibat berkurangnya keindahan pada wajah penderita.

Selain disebabkan oleh hormone, jerawat juga bisa karena adanya 
infeksi bakteri salah satunya adalah propionibacterium. Bakteri ini bisa menginfeksi dalam tubuh manusia. Banyak obat infeksi yang telah beredar baik dari bahan kimia maupun bahan alam. Obat dari bahankimia secara umum dapat menimbulkan berbagai efek samping. Oleh karenanya, masyarakat lebih banyak memilih obat yang kandungannya dari bahan alam, selain lebih aman harganya juga lebih terjangkau (Kumar. P., 2013). Salah satu tumbuhan bermanfaat sebagai obat adalah nangka (Artocarpus heterophyllus. L). Bagian dari tanaman nangka yang sering digunakan sebagai obat adalah daun. Metabolit sekunder dalam daun nangka adalah terpenoid, fenol, glikosida, phytosterol, antraquinon, dan flavanoid. Saponin dan flavonoid mempunyai manfaat sebagai antibakteri yang mekanisme kerjanya menghancurkan membran sitoplasma dan juga mendenaturasi protein sel. Hasil pengujian antibakteri daun nangka terhadap bakteri Escherichia coli menunjukkan adanya zona hambat yang artinya mempunyai efek antibakteri terhadap bakteri E.coli tersebut.

\section{Metode}

Kegiatan pengabdian ini dilakukan melalui seminar menggunakan metode ceramah, tanya jawab dan demonstrasi. Metabolit sekunder yang terkandung dalam buah semangka di identifikasi melalui skrining fitokimia. Proses ekstraksi buah semangka dilakukan menggunakan metode maserasi.

\section{a. Tahap Persiapan}

Materi sosialisasi dipersiapkan dalam bentuk power point.

\section{b. Tahap Pelaksanaan}

Kegiatan sosialisasi dilakukan secara langsung melalui kegiatan seminar.

\section{Hasil Dan Pembahasan}

Ekstrak daun nangka dibuat dalam 5 konsentrasi yaitu $30 \%, 50 \%, 70 \%$, $90 \%$ dengan pelarut aquadest. Pada pengujian evaluasi sediaan krim meliputi uji organoleptik, homogenitas, $\mathrm{pH}$, tipe krim, stabilitas sediaan (cycling test), mikrobiologi sediaan dengan konsentrasi masingmasing formula $30 \%, 50 \%, 70 \%, 90 \%$ dan 1 formula sebagai blangko. Asam stearat $12 \%$ digunakan sebagai basis krim karena dapat menjadikan krim lunak sehingga viskositas krim menjadi rendah. Setil alkohol $0,5 \%$ dan trietanolamine $1 \%$ digunakan sebagai emulgator yang berfungsi untuk menurunkan tegangan permukaan antara fase air dan fase minyak. Emulsi tipe $\mathrm{m} / \mathrm{a}$ setil alkohol dapat meningkatkan stabilitas krim apabila dikombinasi dengan triethanolamin sebagai zat pengemulsi yang larut dalam air.Gliserin $1 \%$ digunakan sebagai humektan. Nipagin $0,2 \%$ dan propilen glikol $3 \%$ sebagai pengawet karena sediaan krim terdiri atas campuran minyak dan air yang mudah ditumbuhi mikroorganisme (Karmilah dan Musdalifah., 2018).

Hasil pengujian organoleptik menunjukkan semua formula memiliki aroma khas seperti daun nangka, formula 1 berwarna putih, formula 2 berwarna putih kehijauan, formula 3 hijaunya lebih muda, formula 4 hijau dan formula 5 berwarna hijau tua. Perbedaan warna tersebut dipengaruhi oleh jumlah konsentrasi zat aktif dalam suatu sediaan krim. Dari uji homogenitas semua sediaan tidak adanya partikel kasar pada sediaan. Pengamatan yang dilakukan terhadap krim menunjukkan tidak ada terjadi inverse fase sehingga memenuhi syarat evaluasi fisik sediaan krim untuk semua formula. Pengujian cycling test yang dilakukan untuk mengetahui kestabilan sediaan krim. Pengujian organoleptik tidak ada terjadi perubahan warna dan aroma. Namun terjadi perubahan bentuk yakni pada formula 3,4, dan 5 dari semi padat menjadi sedikit cair yang dipengaruhi oleh jumlah konsentrasi zat aktif lebih tinggi dibandingkan formula 2. Pada uji mikrobiologi sedian Pada formula dengan konsentrasi 30\% memberikan zona hambat sebesar 9,5 
$\mathrm{mm}$, konsentrasi $50 \%$ pada $11,3 \mathrm{~mm}$, $70 \%$ sebesar $13,5 \mathrm{~mm}$, dan $90 \% 15,2$ mm. Menurut Davis dan stout (1971) apabila diameter zona hambat yang terbentuk memiliki nilai $0-5 \mathrm{~mm}$ itu artinya daya anti bakteri yang dimilki suatu sediaan lemah, 5-20 mm sedang, dan 10-20 $\mathrm{mm}$ daya antibakterinya kuat dan $>20 \mathrm{~mm}$ sangat kuat. Berdasarkan kriteria tersebut maka yang memiliki daya hambat sedang pada konsentrasi 30\%, dan yang memiliki zona hambat kuat pada konsentrasi 50\%, 70\%, 90\%. Penghambatan pertumbuhan bakteri disebabkan oleh senyawa kimia yang terkandung daun nangka berupa tanin, saponin, flavonoid. Senyawa tanin dapat mengerutkan dinding sel sehingga mengganggu permeabilitas selnya. Akibat sel tidak dapat melakukan aktivitas hidup sehinga pertumbuhannya terhambat atau bahkan mati. Sedangkan menurut pratiwi (2008) karena saponin dapat berinteraksi dengan sel bakteri maka dinding selbakteri menjadi pecah, sedangkan flavonoid diduga sebagai salah satu senyawa antibakteri dalam daun nangka dengan menghancurkan protein.

Pada perlakuan klindamisin 0,1 $\%$ memberikan zona hambat $18,9 \mathrm{~mm}$ termasuk kriteria zona hambat sangat kuat pada bakteri Propionibacterium acne, ini dikarenakan klindamisin merupakan antibiotik lincosamida semisintetik yang bersifat bakteriostatik dan juga bersifat bakterisida yang mekanisme kerjanya menghambat pembentukan protein bakteri dengan mengikat secara reversible sub unit ribosom 50S, sehingga menghalangi reaksi transpeptidasi atau translokasi organisme yang rentan yang mengakibatkan pertumbuhan sel terhambat. Hasil yang diperoleh dari sosialisasi ini adalah sebagai berikut:

1. Materi seminar dapat dipahami oleh peserta seminar yang dibuktikan melalui pre test dan post test yang diberikan.

2. Peserta seminar mendapat pengetahuan baru mengenai manfaat dari buah nangka sebagai antibakteri.

\section{Kesimpulan}

Berdasarkan hasil penelitian yang dilakukan, dapat disimpulkan:

1. Daun nangka memiliki aktivitas anti bakteri terhadap Propionibacterium acne yang bisa menyebabkan jerawat.

2. Komponen senyawa ekstrak daun nangka yang berperan sebagai antibakteri, yaitu senyawa flavonoid, tanin, dan saponin.

\section{Ucapan Terimakasih}

Pengabdi mengucapkan terima kasih kepada:

a. Lembaga Penelitian dan Pengabdian Masyarakat INKES Medistra Lubuk Pakam.

b. Semua pihak yang ikut berpartisipasi dalam kegiatan penyuluhan ini

\section{Daftar Pustaka}

Depkes RI. (1995). Materia Medika Indonesia. Jilid VI. Jakarta: Direktorat Jendral Pengawasan Obat dan Makanan. Halaman 247- 251.

Depkes RI. (2010). Suplemen 1 Farmakope Herbal Indonesia. Jakarta: Depertemen Kesehatan Republik Indonesia. Halaman 140- 141.

Ditjen POM RI. (1979). Farmakope Indonesia. Edisi ke tiga. Jakarta: Departemen Kesehatan Republik Indonesia. Halaman 8-9, 32, 896.

Ditjen POM RI. (1985). Formularium Kosmetika Indonesia. Jakarta: Depertemen Kesehatan RI. Halaman 22, 356.

Difco dan BBL Manual. (2009). Manual of Microbiological Culture Media. Edisi II. Sparks: Becton, Dickinson and Company 7 Loveton Circle. Halaman 398, 402. 